\title{
RAPPORT BUILDING IN CLASSROOM: STRATEGIES AND ROLE IN LEARNERS' PERFORMANCE
}

\author{
Resham Acharya*
}

\begin{abstract}
Learners 'performance is mainly based on the quality of interaction between teachers and students. Such interaction between them is based on suitable environment created through mutualunderstanding and professional relationships between teachers and students. Despite this fact, this study has observed that many teachers are unaware about establishing mutual relationships and favourable environment for interaction with the students in their classes. Because of the authoritative behaviours of the teachers, students have issues in learning. This study has attempted to identify what students want to make favourable environment in class and role of rapport building for learners 'performance. The findings of the study reveal that the students had great desire of their teachers to have a sense of harmony with the students to help learners so as to enhance their performances.
\end{abstract}

Key words: Rapport, students-teacher relationships, rapport building strategies, learning performance

\section{INTRODUCTION}

In general sense, rapport, a social and psychological phenomenon, is taken as the ability of an individual to relate to others in a way that creates a level of trust and understanding. In other words, it is an overall feeling between two people encompassing a mutual, trusting and pro-social bond [Catt, Miller \& Schallerkamp, 2007 cited in Dyrenforth (2014)]. Similarly, Faranda and Clarke (2004) define it as the ability to maintain harmonious relationships based on affinity for others. The affinity, according to Bell and Daly (1984), is the active social-communicative process by which individuals attempt to get others to like and to feel positive toward them.

Rapport is taken as an important tool for establishing good relationships between the people in interpersonal communication. Teaching and learning in the classroom is also a form of interpersonal communication, where teacher and students interact each other. This idea is supported by Dobransky and Fymier (2004) who claim that instructor-

* Mr. Acharya is Teaching Assistant in University Campus, Kirtipur, TU 
186 RAPPORT BUILDING IN CLASSROOM: STRATEGIES AND ROLE IN ...

student relationships in the classroom are often interpersonal in nature. It is also generally agreed that success of classroom performance of the students. With the similar vein, Dyrenforth (2014) states that the rapport between instructor and student can be a significant factor in the overall learning and success of individual students. In highlighting the role of rapport in the classroom, Brook field says Durenforth (2014) cited by Brook field says;

Trust between teachers and students are the affective glue that binds educational relationships together. Not trusting teachers has several consequences for students. They are unwilling to submit themselves to the perilous uncertainties of new learning. They avoid risk. They keep their most deeply felt concerns private. They view with cynical reserve the exhortations and instructions (para.2).

Rapport is a term that is truly relationships-centred in capturing what is experienced in interpersonal relationships and can have positive effects in the classroom (Coupland, 2003). Showing the positive effects of rapport in the classroom, it can minimize anxiety, increase student participation, structure and encourage social interaction, foster a positive learning environment, and increase learning.

Rapport improves numerous classroom areas; specially motivation, feedback, student learning and communication. Moreover, it also makes the teacher respected by the students. Therefore, it is fruitful to both the teacher and the students to have a good rapport. Teachers who have good rapport with their students are skilled in "ways that encourage involvement, commitment, and interest" (Ramsden, 2003). In other words, it is useful for the teachers to develop professional skills or knowledge to motivate their students for learning.

As learning results from the interaction between teacher and students, there needs to be close relationships between the teacher and students. That is to say that the close/mutual relationships between teacher and the students create positive environment for the students to learn. Dyrenforth (2014) also identified that perceived rapport with instructors is positively related to classroom connectedness, participation, and overall student learning. Similarly, that instructor rapport enhances almost all facets within classroom. Therefore, rapport in the classroom has significant role to enhance learners 'performance or learning; and thus, it is to be established between teacher and the students; and it is to be initiated by the teachers because students often have fear to speak freely to the teachers. 
There are a number of ways to establish rapport between teachers and students. First is to know the students which involves knowing students' name, calling with name, sharing personal as well as course related information either face-to-face or online. These make the students feel comfortable to speak openly with teachers. Duffy and Jones (1995) also claim that knowing the name of the students is the easiest way to build a trust between teachers and students.

The second is to engage the students within the realm of instruction or in other matters. This indicates that teachers care about the students. For this purpose, Lowman (1995) suggests the teachers to arrive early and stay late in the classroom and have informal talks with them. Engaging the students also involves having interaction outside classroom, playing with them in different activities and sharing experiences. The third is to go further, which shows interests of the teachers in the students. This may involve attending the sports events with the students, congratulating in their success and so on. There may be many more other ways to establish rapport in the classroom.

Despite the fact that rapport building in the classroom plays very important role to motivate the students in learning and it results in their better performance. Conversely, the students like to have close relationship with their teachers so that they can enhance their learning in a comfortable environment. In other words, they want their teachers to show such behaviours that can create a trust between them and the behaviours make the learners feel easy in questioning, interacting, and participating in teaching learning activities. The more they participate in classroom learning, the better they learn, and as a result, they have better performance in learning. Therefore, this study attempted to find out what the students want from their teachers to create friendly environment and how it contributes in learners' performance having two research questions. Key research questions of this study are as follows:

- What are the strategies in building rapport in the classroom? Or What do students want their teachers do to create a good environment in learning?

- What is the role of rapport in learners' performance? 


\section{METHODOLOGY}

To find out the answer of the key research questions stated above, 30 students from University Campus, Kirtipur studying at Faculty of Education were chosen according to purposive non-random sampling procedure. After establishing rapport and telling the purpose of the study, the sampled students were given a set of questionnaire (having close-ended questions) so as to collect data for the study. Then, the collected data were analysed descriptively by using simple statistical tool called as frequency analysis.

\section{RESULT AND DISCUSSION}

The results of the study have been discussed in two sections, i.e. in terms of what students want their teachers do to establish good learning environment by using rapport building strategies and the role of rapport building in learners' performance.

\section{Strategies of rapport building}

Regarding to establish a good learning environment, it was found that the students want their teachers to become close, be familiar with them and create easy learning environment. For this, all the students in the sample want their teachers call them with their name, respond their e-mail, display positive and enthusiastic attitude, do humorous and pleasant interaction, chat on face-book, and create comfortable environment to interact in class. Similarly, they want their teachers to be open in communication, provide examples and evidences in the discussion, respect students' opinions, create comfortable communicating behavior with smile, trust them, and make students participate in teaching learning activities. In similar way, all the students (i.e. 100\%) want their teachers to have eye-contact with students, welcome questions with smile, and be regular. However, in case of teachers sharing personal and course related information and participating in sports events, 83.33 percent and 73.33 percent students respectively responded positively. In contrast, all the students (i.e. 100\%) want their teachers not to show their power in the classroom and outside. They did not expect their teachers to ignore students and their opinions, dominate students, and not interacting with them. The results of what students want from their teachers (Table 1). 
Table 1: Strategies of Rapport Building

\begin{tabular}{|l|l|l|l|l|}
\hline \multirow{2}{*}{ Item } & \multicolumn{2}{|c|}{ Yes } & \multicolumn{2}{c|}{ No } \\
\cline { 2 - 6 } & No. & \multicolumn{1}{|c|}{$\%$} & No. & \multicolumn{1}{|c|}{} \\
\hline Call your name. & 30 & 100.00 & - & - \\
\hline Respond email. & 30 & 100.00 & - & - \\
\hline Display positive and enthusiastic attitude. & 30 & 100.00 & - & - \\
\hline Do humorous and pleasant interaction. & 30 & 100.00 & - & - \\
\hline Chat on face-book. & 30 & 100.00 & - & - \\
\hline Create comfortable environment to interact. & 30 & 100.00 & - & - \\
\hline $\begin{array}{l}\text { Share personal and course related } \\
\text { information. }\end{array}$ & 25 & 83.33 & 5 & 16.67 \\
\hline $\begin{array}{l}\text { Make clear communication with examples } \\
\text { and evidences. }\end{array}$ & 30 & 100.00 & - & - \\
\hline $\begin{array}{l}\text { Respect your opinions or listen to what you } \\
\text { say. }\end{array}$ & 30 & 100.00 & - & - \\
\hline $\begin{array}{l}\text { Create easy communicating behavior with } \\
\text { smile. }\end{array}$ & 30 & 100.00 & - & - \\
\hline Trust you. & 30 & 100.00 & - & - \\
\hline $\begin{array}{l}\text { Make you participate in teaching-learning } \\
\text { activities. }\end{array}$ & 30 & 100.00 & - & - \\
\hline Participate with you in sport event. & 22 & 73.33 & 8 & 26.67 \\
\hline Make eye-contact without staring. & 30 & 100.00 & - & - \\
\hline Welcome the questions with smile. & 30 & 100.00 & - & - \\
\hline Be regular in the class. & 30 & 100.00 & - & - \\
\hline $\begin{array}{l}\text { To show their power in the classroom and } \\
\text { outside. }\end{array}$ & - & - & 30 & 100.00 \\
\hline Ignore you and your opinions. & - & - & 30 & 100.00 \\
\hline Not interact with you. & - & - & 30 & 100.00 \\
\hline Dominate you. & - & - & 30 & 100.00 \\
\hline
\end{tabular}

Source: Field survey, 2017.

Regarding the strategies of rapport building, the students were found to be interested to be their teachers closer, be familiar with them. Which were the means of developing 'mutual, trusting and pro-social bond' (Catt, Miller and Schallerkamp, 2007) and maintaining 'harmonious relationships' (Bell and Daly, 1984). The sampled students wanted their teachers to call them with their name, to respond them positively and enthusiastically by 
creating pleasant situations in interaction, to respect students' questions and to respond them with smile, and others. These findings are similar to what Dyrenforth (2014) found in his study. Similarly, the students did not want their teachers to dominate them and ignore their questions in the classroom.

\section{Role of rapport in learners' learning performance}

The trust between teachers and the students play positive role in learners' learning performance. Regarding why rapport between teachers and students is important, all the sampled students (i.e. 100\%) opined that it had helped them to participate in teaching-learning activities. Similarly, the same percent students opined that it had helped them to raise the questions easily with the teachers, express their opinions easily in the classroom, learn in friendly environment, motivate for learning, and help in learning process as whole. They further claimed that when they had such environments in or outside the classroom, they had better performances in learning (Table 2).

Table 2: Role of Rapport in Learners' Learning Performance

\begin{tabular}{|l|l|c|l|l|}
\hline \multicolumn{2}{|c|}{ Item } & \multicolumn{2}{c|}{ Yes } & \multicolumn{2}{c|}{ No } \\
\cline { 2 - 6 } & No. & \% & No. & $\%$ \\
\hline $\begin{array}{l}\text { To make you participate in teaching-learning } \\
\text { activities. }\end{array}$ & 30 & 100.00 & - & - \\
\hline To make you raise the questions easily. & 30 & 100.00 & - & - \\
\hline To make you interact with teacher easily. & 30 & 100.00 & - & - \\
\hline $\begin{array}{l}\text { To make you express your opinions easily in the } \\
\text { class. }\end{array}$ & 30 & 100.00 & - & - \\
\hline To learn in friendly environment. & 30 & 100.00 & - & - \\
\hline To motivate for learning. & 30 & 100.00 & - & - \\
\hline As a whole to help in learning process. & 30 & 100.00 & - & - \\
\hline
\end{tabular}

Source: Field survey 2017.

Coupland (2003), Dyrenforth (2014), Fribsky and Martin (2010), and Swenson (2010), have shown that rapport between teacher and students in the classroom is like glue that binds educational relationships that positively affect in students' learning. Similar to their findings, this study has also justified a mutual relationship between teachers and the students to achieve positive role in learners' learning performances. For example, it encourages the students to take part in teaching-learning activities, to raise 
questions, to express their opinions comfortably. It helps the students to learn in friendly environment and motivate for learning.

\section{CONCLUSION}

Good rapport between teachers and students makes students motivated and they can participate in teaching-learning activities actively, comfortably and in friendly environment. Therefore, it can be inferred that there is a significant role of rapport in learners' learning performances. Teachers should know their students individually, share information comfortable for interaction, respect students' opinion, and welcome the questions raised by the students happily. It is not appropriate to show authoritative either in the classroom or out of the class. In short, the students want their teachers to show positive attitudes towards to enhance their learning performances. Hence it could be recommended that to increase the performance of students, teachers need to establish harmonious relationships with the students. Similarly, as having interaction between teacher and students is one of the means of establishing rapport, the teachers should engage themselves in interactions with the students to make the students feel more comfortable in learning.

\section{WORKS CITED}

Bell, R.A., \& Daly, J.A. (1984). The affinity seeking function of communication. Communication Monographs, (51), pp. 91-115.

Catt, S., Miller, D. \& Schallerkamp, K. (2007). You are the key: Communicate for learning effectiveness. Education, (127), pp. 369-377.

Coupland, J. (2003). Small talk: Social functions. Research on Language and Social Interactions, (36), pp. 1-6.

Dobransky, N. \& Fymier, A. (2004). Developing teacher-student relationships through out of communication. Communication Quarterly, (52), pp. 211-223.

Duffy, D.K. \& Jones, J.W. (1995). Teaching within the rhymes of the semester. San Francisco: Jossey Bass.

Dyrenforth, T. (2014).Classroom success through rapport-building. Retrieved 7/6/2017 from www.usma.edu/cfe/literature/ dyrenforth/14.pdf 
192 RAPPORT BUILDING IN CLASSROOM: STRATEGIES AND ROLE IN ...

Faranda, W.T and Clarke I. (2004). Student observations of outstanding teaching: Implications for marketing educators. Journal of Marketing Education, 26(3), pp. 271-281.

Lowman, J. (1995). Mastering the techniques of teaching. San Francisco: Jossey Bass.

Ramsden, P. (2003). Learning to teach in higher education ( $2^{\text {nd }}$ ed.). London: Routledge and Falmer. 